DOI: $10.17516 / 1997-1370-0469$

УДК 159.922 .73

\title{
Social and Psychological Aspects of Emotional Response in Childhood
}

\author{
Alexey A. Dmitrieva and Natalia Yu. Verkhoturova ${ }^{\text {** }}$ \\ ${ }^{a}$ Moscow Region State University \\ Mytishchi, Russian Federation \\ ${ }^{b}$ Krasnoyarsk State Pedagogical University named after V.P. Astafiev \\ Krasnoyarsk, Russian Federation
}

Received 03.07.2019, received in revised form 12.08.2019, accepted 26.08.2019

\begin{abstract}
The article presents a theoretical analysis of socio-psychological aspects of emotional response development in childhood. It considers Russian and foreign authors' scientific approaches to understanding of the emotional response phenomenological nature, identification of socio-psychological factors and mechanisms determining its emergence, formation and development in the framework of cultural and historical tradition. It covers scientific concepts, theoretical approaches and doctrines that reveal the improvement of emotional response as a process of hierarchical differentiation in ontogenesis, mediation of emotional reactions by social and content areas, progressive development of regulation, control and management mechanisms initiated by maturation, cognitive and psychosocial development and socialization. The article also focuses on theoretical approaches to outlining of periodization patterns of emotional response formation in childhood, regarding the emotional response as a process that ascends from elementary forms of emotional reflection to higher socially determined, consciously regulated and controlled forms of emotional behavior. In the process of the child's ontogenetic development, these processes turn from externally directed, materialized forms to the level of internal regulation of behavior.

Based on the analysis of existing scientific approaches, the article reveals the deficiencies and identifies the prospects for the research in the field under consideration. It states the necessity of the development of universal complex classification and periodization schemes, reflecting ontogenetic features of progressive development, accumulation and complication of psychological new formations in a multicomponent structural and hierarchical organization of emotional response. The article determines theoretical and practical importance in the development of the conditions for psychological support for the child's emotional response formation and development, implying the introduction of monitoring, forecasting and management technologies for the purposeful formation of the younger generation's emotionally competent behavior.
\end{abstract}

\footnotetext{
(C) Siberian Federal University. All rights reserved

* Corresponding author E-mail address: verhotyrovs@mail.ru

ORCID: 0000-0002-3880-8094 (Dmitriev); 0000-0003-2296-7397 (Verkhoturova)
} 
Keywords: emotional response, emotional reactions, emotional processes, emotional response formation, multilevel system of emotional regulation of behavior.

Research area: social psychology.

Citation: Dmitriev, A.A., Verkhoturova, N. Yu. (2019). Social and psychological aspects of emotional response in childhood. J. Sib. Fed. Univ. Humanit. Soc. Sci., 15(4), 537-545. DOI: 10.17516/1997$1370-0469$.

\section{Problem Statement and Research Objectives}

Psychology has traditionally regarded emotions as complex psychophysiological formations resulting from systemic brain activity, on the one hand, and cultural and historical development of mankind, on the other hand. This understanding of emotions predetermined the emergence of a significant number of Russian and foreign scholars' scientific approaches to phenomenological essence of emotional response, nature and mechanisms of its emergence, as well as to development of a wide variety of taxonomies and periodization schemes of formation and development of emotional regulation of the child's behavior.

Such Russian scholars as L. S. Vygotsky (2000), A. V. Zaporozhets (1985), A.D. Koshelev (2003), O.A. Shagraeva (2003) and others studied the factors and mechanisms of children's emotional response formation. According to their views, human emotions and, thus, the entire system of emotional regulation of behavior are products of social and historical development. The studies state that in the process of ontogenetic evolution, in the course of the child's mental structures improvement and his/her social and cultural experience development the maturation of emotional processes in the form of qualitative new formations built over one another, their role and functions in behavior and activity regulation change.

Development of cultural and historical approach in psychology has led to considering emotional processes as well as other higher mental functions as multi-level and multidimensional formations, structural and hierarchical organization of which is dynamic and develops with age. According to L. S. Vygotsky (2000), in the course of ontogenetic evolution, emotions (like other higher mental functions) acquire a set of characteristics: they become integral, structural, objective, supraliminal, systemic, indirect, controlled, and manageable. These characteristics are not formed from the moment of birth; they consistently evolve in the process of the individual's ontogenetic development and his/her acquisition of social and cultural experience.

Our research is aimed at sociopsychological analysis of modern state of the issue of emotional response formation in children and identification of factors and mechanisms that determine its emergence, development and dynamics of major new formations in the child's emotional sphere, the research being done within the framework of cultural-and-historical tradition. Basing on the analysis of current state of the emotional response problem, we have identified deficiencies and prospects for research in the field.

\section{Theoretical framework}

Analytical review of modern approaches to understanding of nature and determinative dependence of emotional response emergence and maturation points to socio-psychological mechanisms in its origin and development, emotional response being viewed as a multilevel structural and hierarchical new formation, revealed in successive accumulation and complication of basic emotional blocks, qualitative characteristics, properties and functions of emotional processes and in improvement of regulation, control and management skills.

Analysis of the literature and the research available have made it possible to generalize the existing approaches and to identify the sociopsychological mechanisms that determine the emotional response formation in childhood. Among them there is nervous system matura- 
tion, socialization, cognitive, psychosocial and personal development, regulatory constructs improvement, interpersonal relationships, as well as cultural norms and traditions regulating the repertoire of emotional behavior strategies.

In Russian and foreign authors' modern scientific studies (A.V. Zaporozhets (1985); A. D. Kosheleva (2003); R. W. Lazarus (1991); L. A. Sroufe (1996) et al.) the emotional response formation in childhood is considered as a process of progressive development of emotional literacy, ascending from elementary forms of emotional reflection to higher socially determined, consciously regulated and controlled forms of emotional behavior. According to scientific approaches and doctrines, improvement of emotional response in childhood correlates with the processes of maturation, cognitive and personal development, expansion of the field of social contacts and interpersonal interaction with adults and coevals.

A. I. Dontsov (2016) studied interpersonal relations as one of the socio-psychological mechanisms of personality formation in the children's community. According to the scholar, the emotional sphere development takes place in interpersonal relations which form the basis for the development of feelings, experiences, emotional response, and self-control. Alan Sroufe (1996) expressed a similar view, pointing to the dominant role of emotions in regulation and management of both intrapersonal and interpersonal behavior.

Summarizing the previous works, it is worth while pointing out that the approaches developed in psychology are aimed at assessing the child's emotional literacy through the study and analysis of the following changes: a) the functional role of emotional processes; b) differentiation of properties and qualities of emotions; c) understanding of other people's emotional reactions by external expressive signs and the dictionary of emotions; d) recognition of one's own emotional reactions; e) the ability to plan and verbalize the emotional response; f) abilities to regulate and control the external expression of emotional reactions.

In the conceptions of foreign scholars (P.L. Harris (1989); ～R. W. Lazarus (1991); H. Lewis (1989); L. A. Sroufe (1996) et al.) the emotional response formation in childhood is primarily considered through age-related quantitative and qualitative changes in cognitive and personal constructs initiated by maturation, socialization, and cultural impact. According to the researchers, these progressive changes include emotional complexity and susceptibility to emotional expression of others, growth of understanding the meaning of one's own emotions, other people's emotional reactions, and rules of expression and restraint of emotions in situations of social interaction. Herewith, improvement of mechanisms of regulation, control and management in emotional response is stated as the main marker of the emotional reactions maturity status.

Alan Sroufe (1996) claims that the direction of any line of emotional development and complication of emotional behavior forms involve not only the differentiation of properties and qualities of emotional processes but also the growing importance of the role of the subject's cognitive processes and cognitive activity.

Close connection in the development of emotional and cognitive spheres of the child's psyche was pointed out by the classics of Russian psychology (L. S. Vygotsky (2000); A. R. Luriia (2004); S. L. Rubinshtein (2004) et al.). In their researches it is noted that the emotional reaction improvement passes the way which is analogous to that of cognitive development: from natural forms of emotional reflection to higher, sociallydetermined, consciously regulated and controlled forms of emotional behavior. Emotional and cognitive processes are parts of a single whole - human consciousness, mediating complex forms of behavior and activity. They have a complex systemic and hierarchical organization and develop through age under the influence of external cultural and social factors. In the course of the child's ontogenetic development these processes consistently move from externally directed, materialized forms to the level of internal regulation, control and management of emotional response. By this they determine the emergence of complex integrative forms of emotional behavior that demonstrate the formation of self-regulation and self-management abilities.

The result of such a complex integrative interaction of intellectual, volitional and emo- 
tional processes and properties is constellation of a large group of abilities, knowledge and skills revealing the individual's emotional literacy and characterizing his/her behavior in terms of intelligence, consciousness, criticism, controllability, and manageability. Total representation of these characteristics covers such global abilities, knowledge and skills of the individual as the ability to understand the signand-object content of emotional reactions, to distinguish emotional reactions and differentiate them from others; to anticipate and predict the outcome of an emotional response based on assessment of the correspondence of the analytical-and-synthetic relationship between emotional reaction, cause and effect; to analyze, interpret and systematize the experience of emotions and other abilities.

T.I. Shul'ga (2012) studied the psychological features of the formation of emotional-and-volitional regulation in ontogenesis. A series of experimental studies was carried out under her guidance. They resulted in determination of emotional-and-volitional regulation structure, which includes four interrelated and mutually determining components: emotional, volitional, intellectual, and motivational. This served the basis for the description of some features of emotional and volitional regulation formation in preschoolers and primary school pupils. Emergence of a complex of new formations in the considered structural components was taken into account.

Currently, in social psychology and developmental psychology there are several approaches to the construction of periodization schemes of emotional response in childhood. Available periodizations derive from the development of L. S. Vygotsky's theoretical doctrines about multilevel and hierarchical structure of emotional manifestations (2000): from natural forms to higher culturally mediated and socially determined ones.

One of these approaches is A.V. Zaporozhets's periodization (1985), considering the following levels in the child's emotional response development: the first (genetically primary) level of direct elementary emotional reactions and the second level of higher forms of emotional behavior. The scholar associated the origin of higher forms of emotional reflection and regulation of behavior with the child's individual practical experience on his/her mastering of various activities, development of speech function, social standards, requirements and expectations of others.

Development of the idea about complex structural organization of emotions is reflected in A.D. Kosheleva, V.I. Pereguda, O. A. Shagraewa's work (2003). Taking into account the formation of social emotions, the authors present four successive stages of emotional regulation of behavior in childhood: the first level - the somatically conditioned experience; the second level - the affiliated, empathic experience; the third level - instrumental emotions; the fourth level - social emotions proper.

Along with the periodization schemes considered in our work, there are others that also present the contemporary researchers' general view on the issue of emotional response formation in childhood, the response viewed as a multi-level and hierarchical process, ascending from elementary forms of emotional reflection to higher, socially determined, consciously controlled ones of emotional behavior.

The importance of these studies on the issue of emotional response formation in childhood which takes into account the levels of its cumulative development is undeniable. The fact of high relevance and minor elaboration of this issue in theory and practice of psychological knowledge is also indisputable.

\section{Research Results and Discussion}

A. V. Bulgakov's (2015) conception of intergroup adaptation is of great importance for understanding the essence of sociopsychological mechanisms of emotional response formation in childhood. In the theoretical model (2015), emotional phenomena in their development and formation are regarded as components that form the subculture of the society. According to the scholar, the phenomenological basis for the knowledge of their objective reality should be the projection of two aspects. These are structural-and-functional and value-and- ideological ones. We will carry out a socio-psychological analysis of the phenomenological grounds of emotional response 
while taking into account the key aspects of the analysis suggested by the scholar.

In the context of A. V. Bulgakov's doctrine development, structural and functional aspect of the analysis allows us to study the processes of formation, accumulation and complication of emotional response as a multi-component, multifunctional, and multilevel structural and hierarchical formation. As a complex object of the research, multidimensional and multicomponent structure of emotional response can at the same time be both comprehensively studied and substantively concretized in view of the level dynamics of age-related changes for each element of its component organization. This becomes possible within the frame of its structural and functional content analysis.

The following provisions in Russian psychology serve the theoretical basis for identification of structural components of emotional response in our research: a) social determination of emotions (Zaporozhets, Neverovich, Kosheleva, 1985 et al.); b) the role of emotions in cognitive processes and mental activity (Vygotsky, 2000; Rubinshtein, 2004, et al.); c) understanding of emotions as a means of communication (Andreeva et al., 2002 et al.); d) comprehension of emotions as units of interpersonal relations analysis and regulators of interaction between people (Kunitsyn, Kazarinova, Pogol'sha, 2001 et al.); e) the role of emotions in behavior and activity regulation and arbitrary control (Kunitsyn, Kazarinova, Pogol'sha, 2001 et al.).

As a result of the socio-psychological analysis of the structural and functional determinant, we have made an attempt to present the integrity of emotional response as a multidimensional and multicomponent formation, its structural organization containing several different but interrelated and complementary components. Two of them are basic (fundamental) structural components of emotional response: impressive and expressive.

The impressive component is the obligatory aspect of emotional response, revealing the assessment of understanding and differentiation of emotional reactions, understanding of their causation as well as the connection of emotional reaction with the content area. The expressive component is the second basic component of emotional response. It reveals the assessment of expressive mimic expression; saturation and fullness of emotional reactions with optimal content of external expressive means. The other five components (communicative, interactive, perceptive, cognitive, and regulatory) derive from the basic ones. They reveal the content and functional many-sided nature of emotional response as a complex structural and hierarchical socially-induced formation; reflect the subject's emotional literacy and dynamics of its development in childhood.

The study of the mechanisms of emotional response formation within the framework of their value-ideological component analysis and in the context of A. V. Bulgakov's theoretical model of intergroup adaptation allows us to track an individual path of the child's emotional response development. It implies active assignment of social values, cultural norms, traditions and existing rules of behavior in a particular society. Modern science and practice know many approaches of Russian and foreign authors to understanding of the phenomenological nature of emotional response, identification of various socio-psychological factors and mechanisms determining its emergence and development.

On the basis of such a complex multi-sided socio-psychological analysis of the essence and mechanisms of emotional response in childhood (in the context of the study of phenomenological foundations of its structural-and-functional and value-and-ideological determinants), it is possible to carry out the holistic integrative study of emotional response in the unity of its structural components as well as the study of the processes of its progressive development in childhood through a differentiated analysis of the dynamics of accumulation and complication of main qualitative new formations of emotional literacy in each component of its structural organization.

Regarding this research, emotional literacy implies a personal quality that synthesizes knowledge, skills, abilities (the subject's skills and abilities to understand interpersonal relationships that manifest themselves in emotions, to emotionally (in a constructive way) interact with the use of external expressive means in 
emotional response, to control, regulate and manage emotional response in situations of social interaction); personal and social utilitarian experience of their application, as well as the level of the development of dispositions, value orientations, intellectual, personal and regulatory constructs that provide the opportunity to acquire new knowledge and experience of emotional response, their accumulation and effective use in the course of life.

Formation of a holistic integrative quality of emotional literacy by adding (combining) the results of cumulative formation of the complexes of emotional characteristics and abilities of the previous hierarchical levels in their structural and dynamic integrity of the main component-and-block elements (communicative, interactive, perceptive, cognitive, and regulatory) determines the system-forming basis of our conception of emotional response management in childhood in the context of the competence-based approach.

As the child develops, the forms of emotional response become more complex and improved. They represent a complex set of arbitrary and involuntary emotional reactions to the effects of the external and internal environment. The child's consistently accumulated personal and social utilitarian experience of their application, as well as the level of intellectual, personal and regulatory constructs development are formed into higher forms of emotional behavior. Such higher forms are characterized by the integrity of emotional images, their objectivity, generality and mediation, conscious regulation, self-control, and voluntary control.

Despite the unity of Russian and foreign authors' views on understanding the social essence of emergence and development of emotions, periodization dynamics of their development and complexity is assessed by the scholars as per various criteria and grounds. Among the approaches presented in modern literature most of the periodizations are focused on cognitive and regulatory aspects of forming the emotional regulation of the child's behavior. A smaller part of these works highlights the phased character of developing the perceptual component of emotional response by analyzing the dynam- ics of children's understanding of emotional reactions by their external expressive features.

The existing divergence of views undoubtedly predetermines the ambiguity in understanding of the emotional response phenomenon, its component structure and sociopsychological mechanisms of formation. It also creates difficulties in the psychologist's practical activity on monitoring the state of mental maturity of emotional processes and assessing the compliance of their qualitative changes with age periods.

Our socio-psychological analysis suggests that the majority of researchers declare the need to understand the emotional response as a complex, integrative and multicomponent formation characterized by its multi-dimensionality and multi-functionality. However, as a result of the analytical review, we have revealed the lack of complex integrative studies aimed at tracking the dynamics of the emergence of new formations of the entire structural complex of emotional response as a multi-level and multi-component structural and hierarchical formation. As a result, there are no universal criterion-oriented periodizations, which are based on a component-indexed system for assessing progressive development, accumulation and formation of all components of its structural organization. Creation of such periodization should be preceded by a conceptual theoretical and methodological development of a system of the emotional response integrated assessment with identification of technological parameters and indicators for the subsequent study, monitoring and forecasting of the development of all components in the structure.

\section{Conclusions}

The socio-psychological analysis of the issue of emotional response formation in childhood proves that the person's emotional experience changes and gets enriched in the course of his/her cognitive, personal, psychophysical and psychosocial development, improvement of regulatory mechanisms, as well as expanding the field of social interaction with the surrounding reality.

The process of emotional response development includes gradual emergence and com- 
plication of the basal emotional blocks, changing the content of emotions and feelings and their functional role in ontogenesis, mediation of emotional reactions by social and content area; development of adequate perception of other people's emotional reactions by external expressive manifestations, as well as consistent ontogenetic formation of the ability to understand emotional reactions and to subordinate their manifestation to social norms and rules of the community.

A retrospective journey into the issue of socio-psychological analysis of the emotional response formation in childhood shows that there is a wide range of psychological studies reflecting the importance of emotional sphere for the child's mental development, formation of his/her personality, activities, orientation, behavior, and interpersonal interaction. However, despite numerous publications and a wide scope of psychological studies, the issues related to the development of complex classification schemes and universal periodizations that reflect the ontogenetic features of progressive development, accumulation and complication of new formations in a multicomponent structural organization of emotional response remain relevant. The issues of purposeful formation of the younger generation's emotionally competent behavior, development of mechanisms and technologies for managing the processes of emotional response formation and registration in childhood are also urgent.

\section{References}

Andreeva, G.M., Belinskaia, E.P., Dontsov, A.I., Stefanenko, T.G. (2002). Sotsial'naia psikhologiia $v$ sovremennom mire. Uchebnoe posobie dlia vuzov [Social psychology in the modern world. Textbook for university students]. Moscow, Aspekt Press, 335 p.

Bardetskaia, Ya.V., Verkhoturova, N. Yu., Abdulkin, V.V. (2016). Correlates of temperamental features, adaptive responses and conditions in junior schoolchildren. SGEM International Multidisciplinary Scientific Conference on Social sciences and Arts, 1 (1), 117-122.

Bulgakov, A.V. (2015). Printsip kul'turnogo oposredovaniia kak osnova sravnitel'nogo analiza rezul'tatov issledovanii mezhgruppovoi adaptatsii $\mathrm{v}$ organizatsiiakh [The principle of cultural mediation as a basis for the comparative analysis of the research results on intergroup adaptation in organizations]. In Vestnik rossiiskogo gosudarstvennogo gumanitarnogo universiteta: nauchno-prakticheskoe izdanie. Seriia Psikhologiia. Pedagogika. Obrazovanie [Bulletin of the Russian State University for the Humanities: scientific and practical publication. Series: Psychology. Pedagogy. Education], 10 (153), 37-59.

Dmitriev, A.A., Verkhoturova, N. Yu. (2013). K probleme upravleniia emotsional'nym reagirovaniem uchashchikhsia mladshego shkol'nogo vozrasta s narusheniem intellektual'nogo razvitiia [On the problem of controlling emotional responses of elementary school-age pupils of with cognitive development disorder]. In Vestnik Rossiiskogo universiteta druzhby narodov: nauchnyi zhurnal [RUDN Journal of Psychology and Pedagodics], 1, 124-129.

Dmitriev, A.A., Verhoturova, N. Yu. (2018). Emotsional'noe reagirovanie: fenomenologiia, strukturno-komponentnyi sostav, problemy i perspektivy issledovaniia [Emotional response: phenomenology, structural-component composition, problems and prospects of research]. In Sibirskii pedagogicheskii zhurnal [Siberian Pedagogical Journal], 3, 90-96.

Dmitrieva, S.A., Verkhoturova, N. Yu. (2013). Izuchenie psikhologicheskikh simptomokompleksov $\mathrm{u}$ detei-sirot s zaderzhkoi psikhicheskogo razvitiia v protsesse otsenki ikh emotsional'noi kompetentnosti [The study of psychological symptoms in orphans with mental retardation in the process of assessing their emotional competence]. In Spetsial'noe obrazovanie [Special Education], 3, 41-47.

Dontsov, A.I., Dontsov, D.A., Dontsova, M.V., Piatakov, E.O. (2016). Sotsial'no-psikhologicheskie effekty obshcheniia, ikh vliianie na vzaimodeistvie liudei, vozdeistvie ikh na kommunikatsiiu, interaktsiiu i sotsial'nuiu pertseptsiiu [Socio-psychological effects of communication, their influence on people's interaction, their impact on communication, interaction and social perception]. In Vestnik prakticheskoi psikhologii obrazovaniia [Bulletin of practical psychology of education], 3 (48), 30-41. 
Gal'perin, P. Ia. (2002). Lektsii po psikhologii [Lectures on psychology]. Moscow, Knizhnyi dom Un-t; Vyssh. Shkola., $400 \mathrm{p}$.

Harris, P.L. (1989). Children and Emotion. In The Development of Psychological Understanding. Oxford, England, Basil Blackweii, 25-117.

Kosheleva, A.D., Pereguda, V.I., Shagraeva, O.A. (Eds.) (2003). Emotsional'noe razvitie doshkol'nikov [Preschoolers' emotional development]. Moscow, Akademiia, $176 \mathrm{p}$.

Kozyreva, O.A. (2017). Model' inkliuzivnogo obrazovaniia studentov-invalidov i studentov s ogranichennymi osobennostiami zdorov'ia v KGPU im. V.P. Astaf'eva [The model of inclusive education of students with disabilities and students with limited health opportunities in the Krasnoyarsk State Pedagogical University named after V.P. Astaf'ev]. In Alma Mater Vestnik Vysshei shkoly [Alma Mater. Higher School Herald], 4, 75-77.

Kunitsyna, V.N., Kazarinova, N.V., Pogol'sha, V.M. (Eds.) (2001). Mezhlichnostnoe obshchenie: Uchebnik dlia vuzov [Interpersonal communication: Textbook for university students]. Saint Petersburg, Piter, $544 \mathrm{p}$.

Lafrene, P. (2004). Emotsional'noe razvitie detei i podrostkov [Emotional development of children and adolescents]. Saint Petersburg, praim-EVROZNAK, 256 p.

Lazarus, R.W. (1991). Cognition and Motivation. In Amer. Psychol., 46, 352-367.

Lewis, H., Sullivan, M.W., Stanger, C., Weiss, M. (1989). Development and Self-Conscious Emotions. In Child Development, 60, 146-156.

Lisova, N.A., Shilov, S.N. (2017). Osobennosti temperamenta i volevoi samoreguliatsii u studentov sportivnogo i gumanitarnogo proflei obucheniia [Features of temperament and strongwilled self-regulation among students of sports and humanities training profles]. In Vestnik Novosibirskogo gosudarstvennogo pedagogicheskogo universiteta, 7 (3), 72-88. DOI: 10.15293/2226-3365.1703.05.

Luriia, A.R. (2004). Lektsii po obshchei psikhologii [Lectures on general psychology]. Saint Petersburg, Piter, $320 \mathrm{p}$.

Rubinshtein, S.L. (2004). Osnovy obshchei psikhologii [Basics of general psychology]. Saint Petersburg, Piter, $713 \mathrm{p}$.

Savchenkov, Iu.I., Shilov, S.N., Bardetskaia, Ia.V. (2017). Osobennosti chert i struktury temperamenta u iunoshei i devushek-predstavitelei narodov Kavkaza (na primere studentov vuzov g. Krasnoiarska) [Temperament traits and structure in young men and women of Caucasian Ethnicities (exemplified by the students of Krasnoyarsk universities)]. In Zhurnal mediko biologicheskikh issledovanii [Journal of Medical and Biological Research], 5 (2), 13-20. DOI: 10.17238/issn2542-1298.2017.5.2.13.

Shul'ga, T.I. (1994). Problemy volevoi reguliatsii v ontogeneze [Problems of volitional regulation in ontogenesis]. In Voprosy psikhologii [Psychology Issues], 1, 105-111.

Shul'ga, T.I. (2012). Emotsional'no-volevoi komponent psikhologicheskoi gotovnosti k obucheniiu shkol'nikov [Emotional and volitional component of school readiness]. In Vestnik Moskovskogo gosudarstvennogo oblastnogo universiteta. Seriia: Psikhologicheskie nauki [Bulletin of the Moscow Region State University. Series: Psychological Sciences], 1, 60-66.

Sroufe, L.A. (1996). Emotional Development: The Organization of Emotional Life in Early Years. Cambridge, England, Cambridge University Press, 263 p.

Verkhoturova, N. Yu. (2012). Emotsional'noe reagirovanie: funktsii, komponenty, kharakteristiki, problemy i perspektivy issledovaniia [Emotional reacting: functions, components, characteristics, problems and investigation perspectives]. In Vestnik Rossiiskogo universiteta druzhby narodov [RUDN Journal of Psychology and Pedagogics], 1, 94-99.

Verkhoturova, N. Yu. (2012). K probleme opredeleniia struktury i mekhanizmov emotsional'nogo reagirovaniia [To the Problem of Determining the Structure and Mechanisms of the Emotional Reaction]. In Sibirskii pedagogicheskii zhurnal [Siberian Pedagogical Journal], 5, 150-154.

Vygotsky, L.S. (2000). Psikhologiia [Psychology]. Moscow, Eksmo-Press, 1008 p.

Zaporozhets, A.V., Neverovich, Ia.Z., Kosheleva, A.D. (Eds.) (1985). Emotsional'noe razvitie doshkol'nika [Emotional development of a preschooler]. Moscow, Prosveshchenie, 176 p. 


\title{
Социально-психологические аспекты
}

\section{становления эмоционального реагирования}

\section{в детском возрасте}

\author{
А.А. Дмитриев ${ }^{a}$, Н.Ю. Верхотуроваб \\ ${ }^{a}$ Московский государственный областной университет \\ Российская Федерация, Мытищи \\ ${ }^{6}$ Красноярский государственный педагогический \\ университет им. В.П. Астафьева \\ Российская Федераџия, Красноярск
}

\begin{abstract}
Аннотация. В статье представлен теоретический анализ социально-психологических аспектов становления эмоционального реагирования в детском возрасте. Анализируются научные подходы отечественных и зарубежных авторов к пониманию феноменологической природы эмоционального реагирования, определению социально-психологических факторов и механизмов, детерминирующих его возникновение, становление и оформление с позиций культурно-исторической традиции. Освещаются научные концепции, теоретические подходы и учения, раскрывающие совершенствование эмоционального реагирования как процесса иерархической дифференциации в онтогенезе, опосредствования эмоциональных реакций социальным и предметным содержанием, поступательного развития механизмов регуляции, контроля и управления, инициируемых созреванием, когнитивным, психосоциальным развитием и социализацией. Раскрываются теоретические подходы к построению периодизационных схем становления эмоционального реагирования в детском возрасте как процесса, восходящего от элементарных форм эмоционального отражения к высшим социально-детерминированным, сознательно регулируемым и управляемым формам эмоционального поведения.

В процессе онтогенетического развития ребенка данные процессы из внешне направленных, материализованных форм переходят на уровень внутренней регуляции поведения. На основании анализа существующих научных подходов выявлены дефициты и обозначены перспективы исследования в рассматриваемой области. Обосновывается необходимость разработки универсальных комплексных классификационных и периодизационных схем, отражающих онтогенетические особенности поступательного развития, накопления и усложнения психологических новообразований в многокомпонентной структурно-уровневой и иерархической организации эмоционального реагирования. Определяется теоретическая и практическая значимость в разработке условий психологического сопровождения процессами становления, развития и оформления эмоционального реагирования в детском возрасте, с внедрением технологий мониторинга, прогноза и управления целенаправленным формированием эмоционально-компетентного поведения у подрастающего поколения.
\end{abstract}

Ключевые слова: эмоциональное реагирование, эмоциональные реакции, эмоциональные процессы, становление эмоционального реагирования, многоуровневая система эмоциональной регуляции поведения.

Научная специальность: 19.00.05 - социальная психология. 